\title{
Occupational stress and associated factors among health care professionals in Ethiopia: a systematic review and meta- analysis
}

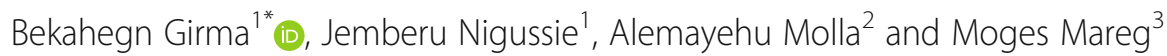

\begin{abstract}
Background: Occupational stress is a global health problem which affects employed personals especially health professionals. The burden of stress is not limited at individual level, but also affects the organizations productivity, the quality of care and country in large. In Ethiopia, little concern is given to this problem and individual studies conducted among health care professionals also showed inconsistent result. Therefore, the aim of this study was to assess the pooled prevalence of occupational stress and its associated factors among health care professionals in Ethiopia.

Methods: Articles were searched from PubMed, Hinari, Psychlnfo, Science direct databases, Google and Google scholar. A total of 10 studies were included in this review and meta-analysis. We used a standardized format for data extraction and STATA software version 13 for analysis. A random effect meta-analysis model was used to determine the pooled prevalence of occupational stress and $I^{2}$ was used to check heterogeneity. Begg's and Egger's tests were conducted to detect publication bias. Furthermore, sensitivity and subgroup analysis was also conducted. Association was expressed by pooled odd ratio with corresponding 95\% Cl.

Results: The pooled prevalence of occupational stress was 52.5 [95\% Cl: $(47.03,57.96)]$. The heterogeneity test was $P^{2}=89.1 \% \& P<0.001$. The result of the publication bias detection (Begg's and Egger's) tests were $p=0.283$ and $p=0.369$ respectively. Female sex was identified as a significant predictor for occupational stress with a pooled effect of 3.75 [95\% Cl: $(2.58,5.45)]$.

Conclusions: Above half of health care professionals had occupational stress. Being female was significantly associated factor in this review and meta-analysis. Therefore, introduction of policies supporting health care professionals well-being at work in Ethiopia are advisable.
\end{abstract}

Keywords: Occupational stress, Health care professionals, Ethiopia, Meta-analysis

\footnotetext{
* Correspondence: Bekahegng@du.edu.et

'Department of Nursing, College of Medicine and Health Science, Dilla University, Dilla, Ethiopia

Full list of author information is available at the end of the article
}

(c) The Author(s). 2021 Open Access This article is licensed under a Creative Commons Attribution 4.0 International License, which permits use, sharing, adaptation, distribution and reproduction in any medium or format, as long as you give appropriate credit to the original author(s) and the source, provide a link to the Creative Commons licence, and indicate if changes were made. The images or other third party material in this article are included in the article's Creative Commons licence, unless indicated otherwise in a credit line to the material. If material is not included in the article's Creative Commons licence and your intended use is not permitted by statutory regulation or exceeds the permitted use, you will need to obtain permission directly from the copyright holder. To view a copy of this licence, visit http://creativecommons.org/licenses/by/4.0/. The Creative Commons Public Domain Dedication waiver (http://creativecommons.org/publicdomain/zero/1.0/) applies to the data made available in this article, unless otherwise stated in a credit line to the data. 


\section{Background}

According to the National Institute of Occupational Safety and Health (NIOSH), occupational stress is defined as "harmful physical and emotional responses that occur when the requirements of the job do not match the capabilities, resources and needs of the worker" [1]. Stress is a response to stressors and can be positive or negative in its nature $[2,3]$.

Different findings showed that individuals and organizations are largely affected by occupational stress. Despite, it affects all employed professionals; the burden is too high among health care providers [4-6]. Occupational stress is a major reason for work related delay, absenteeism, hypertension, musculoskeletal disorders, cardiovascular disorders and substance use [7-11]. Moreover, it is also a major cause of mental disturbance, injuries and staff turnover $[8,12,13]$. It also reduces organizational commitment, job satisfaction, quality of care and organizational productivity [14-20]. Occupational stress is a second work related problem next to low back pain [21].

In the globe, a minimum of 3 million employees frontage grave occupational stress problems and $28 \%$ of employees in European Union are affected by occupational stress [21]. It is also responsible for 50 to $60 \%$ of losses in working days [22]. In 2019, about $83 \%$ of workers suffer from occupational stress in United States (US) and it also caused 120,000 deaths [23]. A finding in systematic review and meta-analysis showed that occupational stress is responsible for an estimated cost of \$221.13 million to $\$ 187$ billion; $70-90 \%$ productivity related losses [24].

The magnitude of occupational stress among health care professionals ranged from 27 to $87.4 \%$ [9, 25-29]. Studies conducted in Ethiopia among health care professionals also showed that 37.8 to $68.2 \%$ of health care professionals had occupational stress [30,31].

Studies conducted in different country showed that factors like; work overload, working unit, work experience, sex, conflict at work place, marital status, educational status, job satisfaction, working environment and not being rewarded were significantly associated with occupational stress among health care professionals [14, 32-34].

Although different studies showed the prevalence of occupational stress among health care professionals, still there is very limited evidence regarding the management of occupational stress $[35,36]$ and in Ethiopia there are no any strategies designed to reduce this problem. Even though there are different single studies in Ethiopia, their results showed a wide range of discrepancy on the prevalence of occupational stress among health care professionals. Therefore, conducting systematic review and meta-analysis is important to provide strong evidence for policy makers and this systematic review and metaanalysis was aimed to assess the pooled prevalence of occupational stress and its associated factors among health care professionals in Ethiopia.

\section{Research questions}

1. What is the pooled prevalence of occupational stress among health care professionals in Ethiopia?

2. What are associated factors of occupational stress among health care professionals in Ethiopia?

\section{Methods \\ Identification of studies}

This systematic review and meta-analysis was conducted in accordance to the guideline of Preferred Reporting Items for Systematic reviews and Meta-Analyses (PRIS MA) [37]. In this review, we explored PubMed, Hinari, and Science direct databases. Goggle scholar and Google searches were also done for grey literatures. In addition, the reference lists of published articles were scrutinized to pinpoint other important articles which didn't accessed in database searches. We started searching of primary articles in June 16/2020 and continued until July 25/2020. We used English language for searching. For objective one, the keywords used were Prevalence AND work related stress OR job related stress OR occupational stress AND health care professionals OR nurse OR doctor OR psychiatrist OR pharmacist OR midwifery AND Ethiopia. We used determinants OR factors OR predictors AND occupational stress OR work related stress AND health care professional's OR nurse OR doctor OR psychiatrist AND Ethiopia to identify associated factors for occupational stress (objective two).

\section{Eligibility criteria of the articles}

We have used a prepared eligibility assessment format to select articles to be included in this systematic review and meta-analysis as stated below.

\section{Inclusion criteria Study settings}

Studies conducted across different regions of the country (Ethiopia) has been considered.

\section{Study design}

Observational studies including cross-sectional, casecontrol and cohort studies with original data reporting at least the prevalence or/and its associated factors of occupational stress among health care professionals were considered. 


\section{Language}

In this review, we included articles published in English language or have English language translation.

\section{Publication status}

Both published and unpublished articles were included in this review.

\section{Study population}

Articles conducted among adult health care professionals in Ethiopian (equal to or age greater than 18 years) were considered.

\section{Study period}

Papers available online since June 16/2020 of July 25/ 2020 were considered.

\section{Data extraction}

Authors (BG and JN) individually extracted all important data using an excel spreadsheet data extraction format. Data extraction format had components like; author name, publication year, population, study design, sample size, response rate, tool and prevalence of occupational stress. Authors used two by two tables to excerpt data for objective two (factors associated with occupational stress), but the factor working unit was not used for analysis because different categories were used [30, 38-40] which was challenging to extract data. So, after extensive communication between the data extractors we decided to remove working unit from meta-analysis. Any other differences during data extraction time between the two authors (BG and JN) were managed through communication with third and the fourth authors.

\section{Outcome measurement}

In this systematic review and meta-analysis, we addressed two objectives. The primary objective was to assess the pooled prevalence of occupational stress among health care professionals in Ethiopia. Occupational stress is harmful physical and emotional responses that occur when the requirements of the job do not match the capabilities, resources and needs of the worker [1]. The prevalence of occupational stress was estimated by dividing the number of health professionals with stress to the total number of health professionals included in the study and multiplied by 100 . The next objective of this review was to determine the pooled effects of factors on occupational stress among health professionals in Ethiopia. To evince the pooled effects, odd ratio (OR) calculated from $2 \times 2$ table was used.

\section{Quality assessment of included studies}

The Ottawa Newcastle Scale adapted for cross sectional study was used to evaluate the qualities of included studies [41]. Using this tool, BG and JN evaluated the studies individually. The tool had three main parts; the first part used to measure the methodological quality of the study, the second part is used to examine the comparability of the study and the last section measures the quality of the studies with respect to statistical method appropriateness. In this review, the quality of each study was assessed and those with high quality (scored 6 and above out of 10) were incorporated for analysis. In the course of this review and meta-analysis, any variations were resolved through discussion and by using the average result of evaluators.

\section{Statistical procedures}

Microsoft excel format was used to extract important data from each study and the extracted data were exported to STATA software version 13 for analysis. Binomial distribution formula was used to calculate the standard error of prevalence for each original article. To check the heterogeneity of the included studies, we conducted $\mathrm{I}^{2}$ test (a measure of the proportion of total variability explained by heterogeneity rather than chance expressed as a percentage) and affirmed as low, moderate, and high heterogeneity if it is < $50,50-75 \%$ and $>75 \%$ respectively [42]. Leave one study out sensitivity analysis was conducted to explore the degree to which the main finding of a systematic review is affected by changes in individual studies [43] by removing one study from the groups and we analyzed the remaining studies to show if there is typical difference in pooled prevalence of study after excluding single study in each group. Furthermore, subgroup analysis was also conducted based on the region where the study was conducted and publication year to identify the source of the random variations between the point estimates of the primary articles. Regarding the publication year in our countries context we observed slight change of health care system in Ethiopia after 2018 and the numbers of mental health professionals and the stress management services are also increasing from time to time. Therefore, we conducted subgroup analysis by publication year considering before and after 2017. To check publication bias funnel plot [44] and Egger's statistical test [45] were conducted. We used a $p$-value $<0.05$ to declare the statistical significance of publication bias.

\section{Result}

\section{Search results}

At the beginning of our search, 152 primary articles were salvaged regarding to the prevalence of occupational stress among health care professionals using PubMed, Science direct, PsychInfo, Hinari, Google and Google scholar searching engines. From the total of 152 articles, 13 articles were exempted due to duplication. 
Furthermore, 127 primary articles were excluded after reviewing their titles and abstracts in which we found them as unrelated to our review and conducted in other setting. Of this, we read the full texts of 12 studies and evaluated them based on our eligibility criteria. Two studies conducted in Ethiopia were also excluded due to poor quality, since the Newcastle Ottawa Scale score less than 6 [46] [Fig. 1].

\section{The characteristics of included articles}

As described in Table 1, 10 (10) primary studies were included in this systematic review and meta-analysis. All of the included studies accompanied a total of 3137 Ethiopian health care professionals with a response rate ranging from $86.1 \%$ [47] to $98.7 \%$ [30]. All of the included primary studies were cross sectional studies and their sample sizes ranges from 138 [48] to 592 [32]. Out of the 10 included primary studies, three were from Amhara regional state [31, 47, 49], two from Addis Ababa city administration [30, 40], two from Oromia regional state $[39,48]$ and three were from Tigray regional state [32], Harari [38] and South Nations Nationality and peoples (SNNP) [50] (one in each). Regarding assessment tool majorities of studies used expanded nursing stress scale [38, 39, 48-50], two studies were conducted by using occupational stress scale [32, 47], another two studies nursing stress scale $[30,48]$ and single study was conducted by perceived stress scale which was modified to assess stress at workplace rather than stress at home [31].

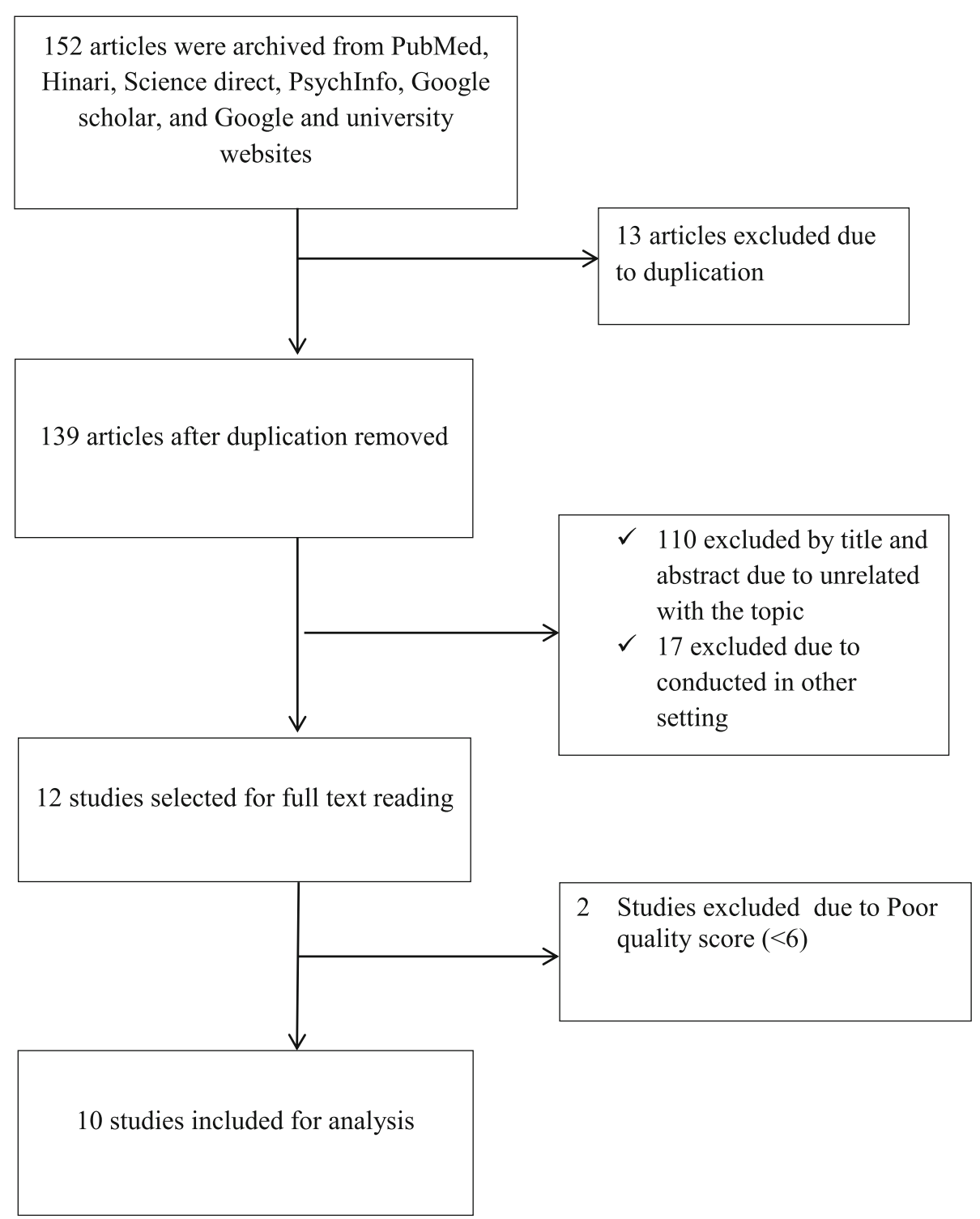

Fig. 1 Flowchart of selected articles included in this systematic review and meta-analysis, Ethiopia, 2020 
Table 1 Distribution of studies included in this systematic review and meta-analysis, 2020

\begin{tabular}{|c|c|c|c|c|c|c|c|c|c|}
\hline Region & Author & $\begin{array}{l}\text { Publication } \\
\text { year }\end{array}$ & Design & $\begin{array}{l}\text { Sample } \\
\text { size }\end{array}$ & Population & $\begin{array}{l}\text { Response } \\
\text { rate }\end{array}$ & $\begin{array}{l}\text { Quality } \\
\text { score }\end{array}$ & $\begin{array}{l}\text { Prevalence } \\
\text { rate }\end{array}$ & Tool \\
\hline Tigray & Tafesse et al. [32] & 2018 & Cross sectional & 592 & $\begin{array}{l}\text { All health care } \\
\text { professionals }\end{array}$ & 94.4 & 9 & 46.9 & OCS \\
\hline \multirow[t]{3}{*}{ Amhara } & Haile et al. [40] & 2017 & Cross sectional & 181 & Nurse & 98.3 & 7 & 57.3 & ENSS \\
\hline & Zeleke et al. [38] & 2019 & Cross sectional & 294 & $\begin{array}{l}\text { All health care } \\
\text { professionals }\end{array}$ & 86.1 & 8 & 48.6 & OCS \\
\hline & Birhanu et al. [31] & 2018 & Cross sectional & 208 & $\begin{array}{l}\text { All health care } \\
\text { professionals }\end{array}$ & 95 & 7 & 68.2 & Modified PSS \\
\hline \multirow[t]{2}{*}{ Oromia } & Worku et al. [39] & 2020 & Cross sectional & 405 & Nurse & 94 & 7 & 53 & ENSS \\
\hline & Nemera et al. [42] & 2018 & Mixed & 180 & Nurse & 98.3 & 6 & 49.2 & ENSS \\
\hline \multirow[t]{2}{*}{ Addis Ababa City } & Zewdu et al. [30] & 2014 & Cross sectional & 343 & Nurse & 93 & 7 & 37.8 & NSS \\
\hline & Tekletsadik et al. [39] & 2020 & Cross sectional & 398 & $\begin{array}{l}\text { All health care } \\
\text { professionals }\end{array}$ & 98.7 & 8 & 46.8 & NSS \\
\hline SNNP & Anand et al. [44] & 2018 & Cross sectional & 138 & Nurse & 97.8 & 6 & 56.3 & ENSS \\
\hline Harari & Baye et al. [43] & 2015 & Cross sectional & 398 & Nurse & 92.2 & 6 & 62.2 & ENSS \\
\hline
\end{tabular}

Note: ENSS Expanded nursing stress scale, NSS Nursing stress scale, OCS Occupational stress scale, PSS perceived stress scale

\section{Meta-analysis}

As shown in Fig. 2, the forest plot was conducted to show the result of the included studies. The pooled prevalence of occupational stress among health professionals in Ethiopia was 52.5 [95\% CI: (47.03, 57.96)]. With regard to heterogeneity, $\mathrm{I}^{2}$ was conducted and there was high heterogeneity as evidenced by $\mathrm{I}^{2}=89.1 \%$ and $p<0.001$. Therefore, random effect model was used to estimate the pooled prevalence of occupational stress among health care professionals in Ethiopia. To detect publication bias, funnel plot was conducted as shown on Fig. 3. In addition, the objective statistical tests, Begg's and Eggers' tests were done and there was no evidence for publication bias $(P=0.283$ and $P=$ $0.369)$ respectively.
Study

Haile et al (2017)

Worku et al (2020)

Zewdu et al (2014)

Anand et al (2018)

Nemera et al (2018)

Baye et al (2015)

Tekletsadik et al (2020)

Zeleke et al (2019)

Birhanu et al (2018)

Tafese et al (2018)

Overall (I-squared $=89.1 \%, p=0.000)$

NOTE: Weights are from random effects analysis
ES $(95 \% \mathrm{Cl})$

$57.30(50.03,64.57)$

$53.00(47.99,58.01)$

$37.80(32.49,43.11)$

$56.30(47.93,64.67)$

$49.20(41.83,56.57)$

$62.20(57.24,67.16)$

$46.80(41.87,51.73)$

$48.60(42.44,54.76)$

$68.20(61.71,74.69)$

$46.90(42.76,51.04)$

$52.50(47.03,57.96)$

Fig. 2 Forest plot of the included studies to determine the pooled prevalence of occupational stress among health care professionals in Ethiopia, 2020 
Funnel plot with pseudo 95\% confidence limits

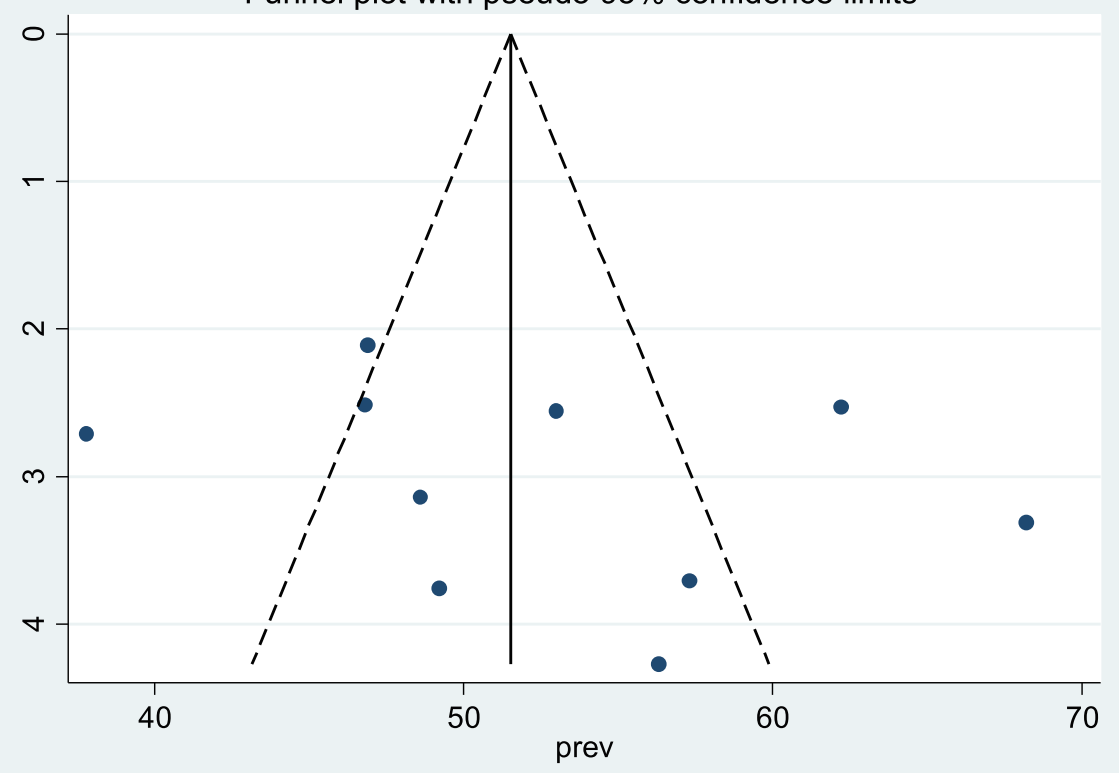

Fig. 3 Funnel plot to assess publication bias among included studies, 2020

\section{Sensitivity and subgroup analysis}

The result showed a pooled prevalence ranges between 50.75 [95\% CI: $(45.8,55.69)]$ and 54.15 [95\% CI: (49.16, 59.14)] [Table 2]. A subgroup analysis was also conducted to address whether the summary effects varies in relation to specific characteristics of the studies. The result of subgroup analysis based on the region where the studies conducted showed that health care professionals in Addis Ababa city administration had lowest prevalence of occupational stress; 42.36\% [95\% CI: (33.54, 51.18)] whereas, the highest prevalence was shown in Harari; 62.2\% [95\% CI $(57.24,67.16)$ ] [Table 3]. We also

Table 2 Sensitivity analysis of the prevalence of occupational stress among health professionals in Ethiopia through leave-one study-out technique, 2020

\begin{tabular}{llll}
\hline $\begin{array}{l}\text { Author name and } \\
\text { publication year }\end{array}$ & $\begin{array}{l}\text { Pooled } \\
\text { prevalence with } \\
\mathbf{9 5 \% ~ C l}\end{array}$ & \multicolumn{2}{l}{ Heterogeneity } \\
\cline { 4 - 5 } & $\mathbf{I}^{\mathbf{2}}$ (\%) & $\boldsymbol{P}$ value \\
\hline Haile et al., 2017 [40] & $52.00[46.12,57.88]$ & 90.0 & $P<0.01$ \\
Worku et al., 2020 [39] & $52.46[46.2658 .66]$ & 90.2 & $P<0.01$ \\
Zewdu et al., 2014 [30] & $54.15[49.16,59.14]$ & 85.1 & $P<0.01$ \\
Anand et al., 2018 [44] & $52.12[46.26,57.99]$ & 90.1 & $P<0.01$ \\
Nemera et al., 2018 [42] & $52.85[46.90,58.81]$ & 90.2 & $P<0.01$ \\
Baye et al., 2015 [43] & $51.34[45.93,56.74]$ & 87.1 & $P<0.01$ \\
Tekletsadik et al., 2020 [39] & $53.17[47.10,59.24]$ & 89.8 & $P<0.01$ \\
Zeleke et al., 2019 [38] & $52.94[46.91,58.97]$ & 90.2 & $P<0.01$ \\
Birhanu et al., 2018 [31] & $50.75[45.81,55.69]$ & 85.4 & $P<0.01$ \\
Tafesse et al., 2018 [32] & $53.18[47.02,59.34]$ & 89.5 & $P<0.01$ \\
\hline
\end{tabular}

conducted subgroup analysis by publication year. Subgroup analysis by publication year showed approximately similar prevalence of occupational stress among studies conducted in 2017 and before, and after 2017; 52.4 [95\% CI; $(36.52,68.27)]$ and 52.49 [95\% CI: $(47.1,57.87)]$ respectively. But the heterogeneity of studies conducted in 2017 and before was high $\left(\mathrm{I}^{2}=95.6 \%, p<0.001\right)$ as compared to studies conducted after $2017\left(\mathrm{I}^{2}=83.6 \%\right.$, $p<0.001)$ [Table 3].

\section{Factors associated with occupational stress}

In the included primary studies, a lot of factors were identified as predictors for occupational stress. But in this systematic review and meta-analysis, factors that were recorded in at least three primary articles were taken for meta-analysis. We identified sex [30, 32, 48, 49], marital status [30, 32, 39, 48], work experience [32, $39,47,49$ ] and working unit as factors for occupational stress among health care professionals in Ethiopia.

From the included factors, only sex of the health care professionals was identified as a predictor for occupational stress as evidenced by a pooled effect of 3.75 [95\%CI: $(2.58,5.45)$ ] [Fig. 4]. Female participants had 3.7 times greater odds of having occupational stress as compared to their counterparts. The other two factors; marital status and working experience had no association with occupational stress as evidenced by their confidence interval including 1; 1.82 [95\% CI: (0.31, 10.7)] and 1.43 [95\% CI: $(0.23,8.86)$ ] respectively [Figs. 5 \& 6]. 
Table 3 Subgroup prevalence of occupational stress among health care professionals in Ethiopia, $2020(n=10)$

\begin{tabular}{|c|c|c|c|c|c|}
\hline \multirow[t]{2}{*}{ Variables } & \multirow[t]{2}{*}{ Characteristics } & \multirow{2}{*}{$\begin{array}{l}\text { No. of } \\
\text { studies }\end{array}$} & \multirow{2}{*}{$\begin{array}{l}\text { Prevalence }(95 \% \\
\mathrm{Cl})\end{array}$} & \multicolumn{2}{|c|}{ Heterogeneity } \\
\hline & & & & $\mathrm{I}^{2}(\%)$ & $P$-value \\
\hline \multirow[t]{6}{*}{ Region and city Administration } & Amhara & 3 & $58.01[46.39,69.62]$ & $89.1 \%$ & $P<0.01$ \\
\hline & Oromia & 2 & $51.80[47.65,55.94]$ & $0 \%$ & $P=0.40$ \\
\hline & Addis Ababa city & 2 & $42.36[33.54,51.18]$ & $83.1 \%$ & $P=0.01$ \\
\hline & SNNP & 1 & $56.30[47.93,64.67]$ & - & - \\
\hline & Tigray & 1 & $46.90[42.76,51.04]$ & - & - \\
\hline & Harari & 1 & $62.20[57.24,64.67]$ & - & - \\
\hline \multirow[t]{2}{*}{ Publication year } & 2017 and before & 3 & $52.40[36.52,68.27]$ & 95.6 & $P<0.01$ \\
\hline & After 2017 & 7 & $52.50[47.03,57.96]$ & 83.6 & $P<0.01$ \\
\hline
\end{tabular}

\section{Discussion}

In this review and meta-analysis, the pooled prevalence of occupational stress was 52.5 [95\% CI: $(47.03,57.96)]$. This finding was almost comparable with studies done in Portugal (50\%) [51], South Africa (51\%) [52] and Iran (49.5\%) [53]. However, it was high as compared to studies done in Saudi Arabia (45.5\%) [54], Jordan (30\%) [55] and Australia (41.2\%) [56]. Whereas, it was low as compared to studies done in India (87.4\%) [9], Iran (78.4\%) [57], Saudi Arabia (66.2\%) [26] and United Kingdom (59\%) [58].

The findings of different studies showed that the prevalence of occupational stress among health care professionals varies by countries, tools and socioeconomic levels. It is important to consider that this research is based on the results of 10 studies, while the researches in other countries are based different numbers of articles. To explain the possible reasons for the variations of findings within countries, the first reason might be due to discrepancy in sample size and study population. For instance, in studies conducted at India and Iran the study participants were only nurses and the general population were used in Australia.

The other possible reason for the difference might be due to variations in socioeconomic level and measurement tool; in Saudi [54] and Jordan [55] occupational stress scale [55] which had some variation in numbers of components as compared to nursing stress scales [59] that was used by most of studies included in this review.

Regarding the factors associated with occupation stress among health care professionals, being female had higher odds of developing occupational stress; OR: 3.75 [95\% CI: $(2.58,5.45)]$ and was similar with studies done in Iran [60], United Kingdom [58] and Japan [61]. This

Reference groups were male

Study

ID

OR $(95 \% \mathrm{Cl})$

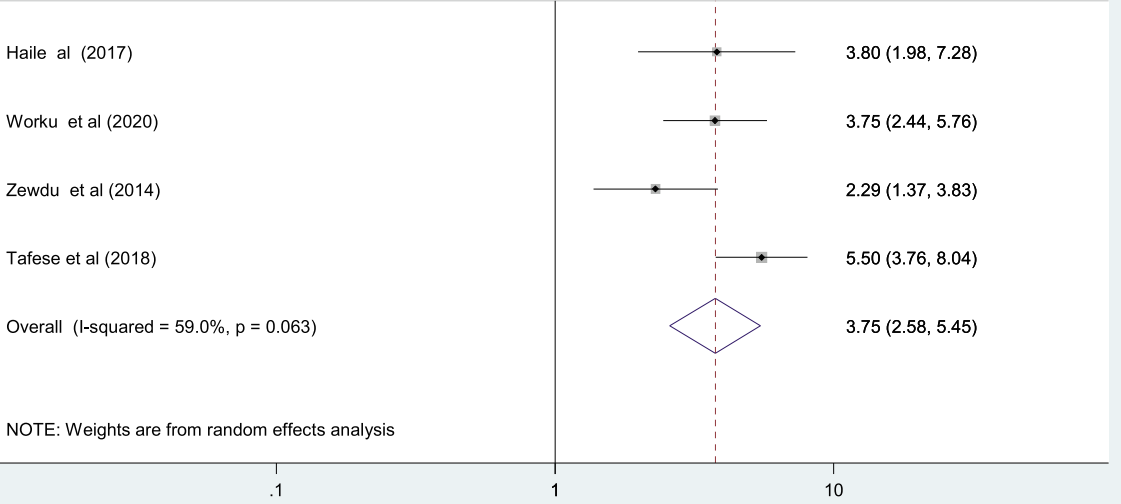

Fig. 4 Association between sex and occupational stress among health care professionals in Ethiopia, 2020 


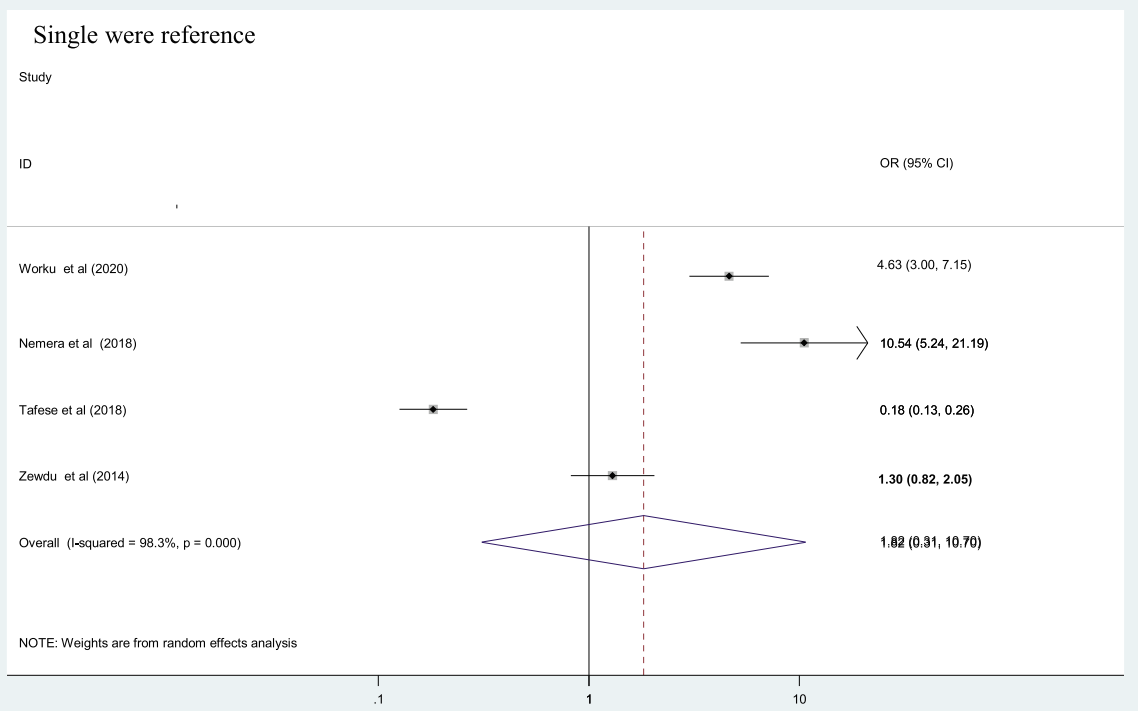

Fig. 5 Association between marital status and occupational stress among health care professionals in Ethiopia, 2020

might be because of female had multiple role outside their work place. However, study done in Nigeria showed no difference [29]. The reason could be as a result of difference in socio-cultural and study population.

The first limitation of this study might be due to the cross sectional nature of the included studies which couldn't show the temporal relationship between the outcome and independent variables. The second, un- proportional distribution of study subjects (nurses number were high). The last limitation might be due to presence of heterogeneity between studies, as result readers should consider during using this finding.

\section{Conclusion}

The finding of this review and meta-analysis showed that half of health professionals in Ethiopia experienced

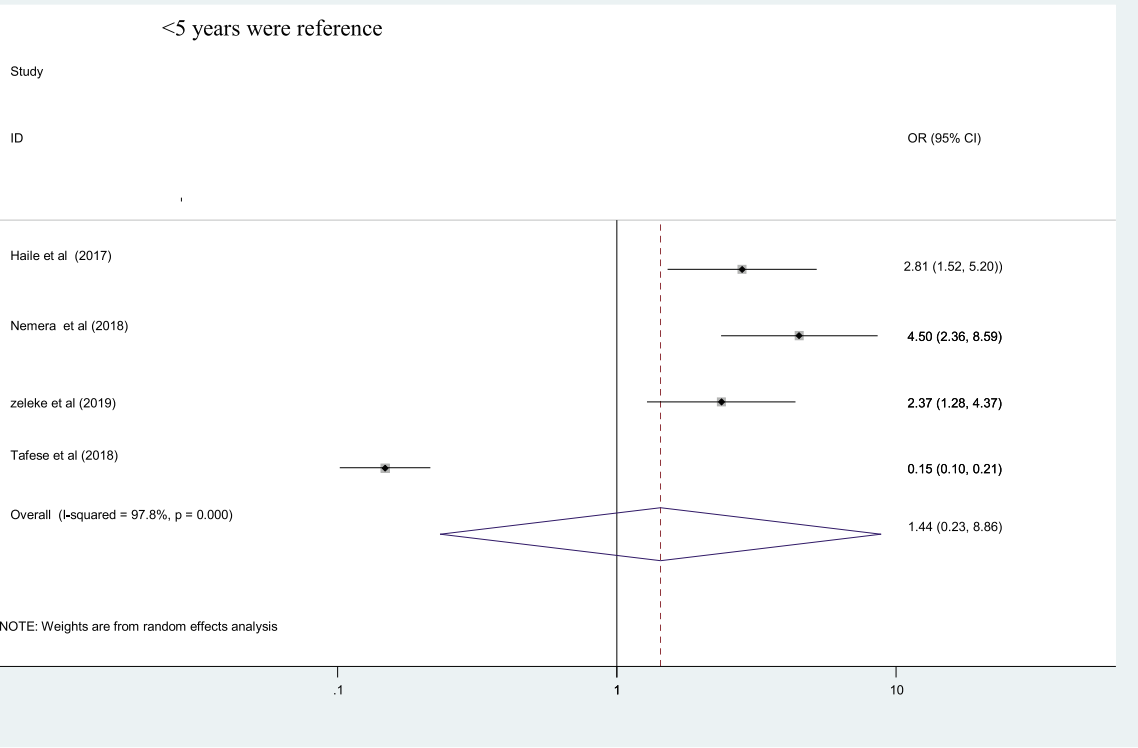

Fig. 6 Association between work experience and occupational stress among health care professionals in Ethiopia, 2020 
occupational stress. Being female participant was significant predictor for occupational stress. Therefore, introduction of policies supporting health care professionals well-being at work in Ethiopia are advisable, in addition to the analysis of its impact on the health care system. Although the analysis of the effects of occupational stress among health care providers was not analyzed, this review underlined that this global problem warrants further research in developing country.

\section{Abbreviations}

Cl: Confidence interval; OR: Odd ratio; SNNP: South Nations and Nationalities People

\section{Acknowledgements}

None

\section{Authors' contributions}

BG and JN conceived the idea, participated in data extraction, analysis, and draft writing. AM and MM participated in analysis, manuscript preparation and revision. All authors read and approved the final version of the manuscript to be considered for publication.

\section{Funding}

Not applicable.

\section{Availability of data and materials}

The data included in this study is available and can be accessed by contacting the corresponding author through this email address; bekahegngi@gmail.com or Bekahegng@du.edu.et.

\section{Declarations}

Ethics approval and consent to participate

Not applicable.

\section{Consent for publication}

Not applicable.

\section{Competing interests}

All authors declare that they have no competing interests.

\section{Author details}

'Department of Nursing, College of Medicine and Health Science, Dilla University, Dilla, Ethiopia. ${ }^{2}$ Department of Psychiatry, College of Medicine and Health Science, Dilla University, Dilla, Ethiopia. ${ }^{3}$ Department of Reproductive Health, College of Medicine and Health Science, School of Public Health, Dilla University, Dilla, Ethiopia.

\section{Received: 15 August 2020 Accepted: 7 March 2021}

\section{Published online: 19 March 2021}

\section{References}

1. NIOSH C: Exposure to Stress: Occupational Hazards in Hospitals. Department of Health and Human Services centers for Disease Control and Prevention National Institute DHHS (NIOSH) Publication 2008(2008-136): 2136.

2. Ismail A, Yao A, Yeo E, Lai-Kuan K, Soon-Yew J. Occupational stress features, emotional intelligence and job satisfaction: an empirical study in private institutions of higher learning. Negotium. 2010;6(16):5-33.

3. Shinde M, Patel S. Co-relation between problematic internet use and mental health in professional education students. Int J Sci Res. 2014;3(2): 194-202.

4. Beh L-S, Loo L-H. Job stress and coping mechanisms among nursing staff in public health services. Int J Acad Res Bus Soc Sci. 2012;2(7):131.

5. Sharifah Zainiyah S, Afiq I, Chow C, Siti Sara D. Stress and its associated factors amongst ward nurses in a public hospital Kuala Lumpur. Malaysian J Public Health Med. 2011;1:1.

6. Tsai Y-C, Liu C-H. Factors and symptoms associated with work stress and health-promoting lifestyles among hospital staff: a pilot study in
Taiwan. BMC Health Serv Res. 2012;12(1):199. https://doi.org/10.1186/14 72-6963-12-199.

7. Bernal D, Campos-Serna J, Tobias A, Vargas-Prada S, Benavides FG, Serra C. Work-related psychosocial risk factors and musculoskeletal disorders in hospital nurses and nursing aides: a systematic review and meta-analysis. Int J Nurs Stud. 2015;52(2):635-48. https://doi.org/10.1016/j.jinurstu.2014.11.003.

8. AlHajjar B: Occupational stress among hospital nurses in Gaza-Palestine Occupational stress among hospital nurses in Gaza-Palestine 2013.

9. Bhatia N, Kishore J, Anand T, Jiloha RC. Occupational stress amongst nurses from two tertiary care hospitals in Delhi. Aust Med J. 2010;3(11):731.

10. Urbanetto JS, Magalhaes MCC, Maciel VO, SantAnna VM, Gustavo AS, Polide-Figueiredo CE, TSBdS M. Work-related stress according to the demandcontrol model and minor psychic disorders in nursing workers. Rev Escola Enfermagem USP. 2013;47(5):1180-6. https://doi.org/10.1590/50080-62342 0130000500024

11. Yaribeygi H, Panahi Y, Sahraei H, Johnston TP, Sahebkar A. The impact of stress on body function: a review. EXCLI J. 2017:16:1057.

12. Hsu HY, Chen SH, Yu HY, Lou JH. Job stress, achievement motivation and occupational burnout among male nurses. J Adv Nurs. 2010;66(7):1592-601. https://doi.org/10.1111/j.1365-2648.2010.05323.x.

13. Thomas $L$, Valli A. Levels of occupational stress in doctors working in a south African public-sector hospital: issues in medicine: SAMJ forum. S Afr Med J. 2006;96(11):1162-8.

14. Dagget T, Molla A, Belachew T. Job related stress among nurses working in Jimma Zone public hospitals, south West Ethiopia: a cross sectional study. BMC Nurs. 2016;15(1):39. https://doi.org/10.1186/s12912-016-0158-2.

15. Onasoga OA, Osamudiamen OS, Ojo A. Occupational stress management among nurses in selected hospital in Benin city, Edo state, Nigeria. Eur J Exp Biol. 2013;3(1):473-81.

16. Fiabane E, Giorgi I, Musian D, Sguazzin C, Argentero P. Occupational stress and job satisfaction of healthcare staff in rehabilitation units. Med Lavoro. 2012;103(6):482-92.

17. Chao M-C, Jou R-C, Liao C-C, Kuo C-W. Workplace stress, job satisfaction, job performance, and turnover intention of health Care Workers in Rural Taiwan. Asia Pac J Public Health. 2015;27(2):NP1827-36. https://doi.org/10.11 77/1010539513506604

18. Faraji O, Ramazani AA, Hedaiati P, Aliabadi A, Elhamirad S, Valiee S. Relationship between job characteristics and organizational commitment: a descriptive analytical study. Iran Red Crescent Med J. 2015;17:11.

19. Teng Cl, Hsiao FJ, Chou TA. Nurse-perceived time pressure and patientperceived care quality. J Nurs Manag. 2010;18(3):275-84. https://doi.org/1 0.1111/j.1365-2834.2010.01073.x.

20. Kemper K, Bulla S, Krueger D, Ott MJ, McCool JA, Gardiner P. Nurses' experiences, expectations, and preferences for mind-body practices to reduce stress. BMC Complement Altern Med. 2011;11(1):26. https://doi.org/1 0.1186/1472-6882-11-26.

21. Eleni M, Fotini A, Maria M, loannis ZE, Constantina K, Theodoros CK. Research in occupational stress among nursing staff-a comparative study in capital and regional hospitals. Sci J Hell Regul Body Nurses. 2010:3(3):79-84.

22. Jamal M. Job stress, job performance and organizational commitment in a multinational company: An empirical study in two countries. Int J Bus Soc Sci. 2011;2:20

23. American institute of stress (AIS): 42 Worrying Workplace Stress Statistics. In. September 25th, 2019.

24. Hassard J, Teoh KR, Visockaite G, Dewe P, Cox T. The cost of work-related stress to society: a systematic review. J Occup Health Psychol. 2018;23(1):117. https://doi.org/10.1037/ocp0000069.

25. Pawlina M, Schnorr G: Prevalence of stress in health workers in the context hospital. Psychol Behav Med Open Access J 2018(0):15-21.

26. Salam A: Job stress and job satisfaction among health care professionals. In: Qatar Foundation Annual Research Conference Proceedings Volume 2016 Issue 1: 2016: Hamad bin Khalifa University Press (HBKU Press); 2016: HBOP2571.

27. Boran A, Shawaheen M, Khader Y, Amarin Z, Hill Rice V. Work-related stress among health professionals in northern Jordan. Occup Med. 2012;62(2):1457. https://doi.org/10.1093/occmed/kqr180

28. Onowhakpor A, Abdulkabir A, Okojie O. Occupational stress: prevalence, sources and coping mechanisms among medical doctors in a tertiary institution. TNHJ. 2018;18:34-44.

29. Adeolu J, Yussuf O, Popoola O. Prevalence and correlates of job stress among junior doctors in the university college hospital, Ibadan. Ann Ibadan Postgrad Med. 2016;14(2):92-8. 
30. Salilih SZ, Abajobir AA. Work-related stress and associated factors among nurses working in public hospitals of Addis Ababa, Ethiopia: a crosssectional study. Workplace Health Saf. 2014;62(8):326-32. https://doi.org/1 0.1177/216507991406200803.

31. Birhanu M, Gebrekidan B, Tesefa G, Tareke M. Workload determines workplace stress among health professionals working in Felege-Hiwot referral hospital, Bahir Dar, Northwest Ethiopia. J Environ Public Health. 2018:2018:1.

32. Godifay G, Worku W, Kebede G, Tafese A, Gondar E. Work related stress among health care workers in Mekelle City administration public hospitals, North Ethiopia. Work. 2018:46.

33. Panhwar GA, Badil B, Shaikh GM, Sherali S, Ghouri A. JOB RELATED STRESS AND ITS VARIOUS SOURCES AMONG NURSES WORKING AT LIAQUAT UNIVERSITY HOSPITAL, JAMSHORO. Pak J Med Dentist. 2019;8(2):5-5.

34. Moustaka E, Constantinidis TC. Sources and effects of work-related stress in nursing. Health Sci J. 2010;4(4):210.

35. West CP, Dyrbye LN, Erwin PJ, Shanafelt TD. Interventions to prevent and reduce physician burnout: a systematic review and meta-analysis. Lancet. 2016;388(10057):2272-81. https://doi.org/10.1016/S0140-6736(16)31279-X.

36. Bresesti I, Folgori L, De Bartolo P. Interventions to reduce occupational stress and burn out within neonatal intensive care units: a systematic review. Occup Environ Med. 2020;77(8):515-9. https://doi.org/10.1136/ oemed-2019-106256.

37. Liberati A, Altman DG, Tetzlaff J, Mulrow C, Gøtzsche PC, loannidis JP, Clarke M, Devereaux PJ, Kleijnen J, Moher D. The PRISMA statement for reporting systematic reviews and meta-analyses of studies that evaluate health care interventions: explanation and elaboration. J Clin Epidemiol. 2009;62(10):e1e34. https://doi.org/10.1016/j.jclinepi.2009.06.006.

38. Baye Y: Work-Related Stress And Associated Factors Among Nurses Working In Governmental Hospitals Of Harari People's National Regional State, Eastern Ethiopia, 2015.University of Gonder 2015

39. Nemera A: Assessment Of Job Related Stress And Its Peredictors Among Nurses Working In Government Hospitals Of West Shoa Zone, Oromia Region, Ethiopia, 2018. Addis Ababa University; 2018.

40. Tekeletsadik S, Mulat H, Necho M, Waja T. Occupational stress and its associated factors among health care professionals working at a setting of a specialized mental hospital. Addis Ababa: Longdom Publishing SL; 2017. p. 2161-0487.2120.

41. Peterson J, Welch V, Losos M, Tugwell P. The Newcastle-Ottawa scale (NOS) for assessing the quality of nonrandomised studies in meta-analyses. Ottawa: Ottawa Hospital Research Institute; 2011.

42. Higgins JP, Thompson SG, Deeks JJ, Altman DG. Measuring inconsistency in meta-analyses. BMJ. 2003;327(7414):557-60. https://doi.org/10.1136/bmj.327. 7414.557.

43. Normand SLT. Meta-analysis: formulating, evaluating, combining, and reporting. Stat Med. 1999;18(3):321-59. https://doi.org/10.1002/(SICI)1097-02 58(19990215)18:3<321::AID-SIM28>3.0.CO;2-P.

44. Sterne JA, Egger M. Funnel plots for detecting bias in meta-analysis: guidelines on choice of axis. J Clin Epidemiol. 2001;54(10):1046-55. https:// doi.org/10.1016/S0895-4356(01)00377-8.

45. Egger M, Smith GD, Schneider M, Minder C. Bias in meta-analysis detected by a simple, graphical test. BMJ. 1997;315(7109):629-34. https://doi.org/1 0.1136/bmj.315.7109.629.

46. Haileyesus G: Work related stress among anesthetists in Addis Ababa hospitals: prevalence and associated factors. Addis Abeba University November, 2014

47. Gebeyehu S, Zeleke B. Workplace stress and associated factors among healthcare professionals working in public health care facilities in Bahir Dar City, Northwest Ethiopia, 2017. BMC Res Notes. 2019;12(1):249. https://doi. org/10.1186/s13104-019-4277-1

48. Hailu BW, Ejigu Y, Siraneh Y, Mekonnen A, Awoke Z. Occupational stress and associated factors among nurses working in public hospitals of Arsi Zone, Oromia regional state, Central Ethiopia, 2018. Science. 2020;6(2):17-28.

49. Kassa DH, Afenigus AD, Meteku BT, Mengisitie BL, Telila BD. Assessment of occupational stress and associated factors among nurses in east Gojjam Zone public hospitals Northwest Ethiopia, 2016. Clin Med Res. 2017;6(2):43. https://doi.org/10.11648/j.cmr.20170602.13.

50. Anand S, Mejid A. Prevalence and associated factors of work related stress among nurses working in worabe comprehensive and specialized hospital, south West Ethiopia. Prevalence. 2018;3(3):260-6.
51. Joaquim A, Custódio S, Savva-Bordalo J, Chacim S, Carvalhais I, Lombo L, Lopes H, Araújo A, Gomes AR: Burnout and occupational stress in the medical residents of oncology, hematology and radiotherapy: a prevalence and predictors study in Portugal. 2018.

52. Govender I, Mutunzi E, Okonta H. Stress among medical doctors working in public hospitals of the Ngaka Modiri Molema district (Mafikeng health region), north West province, South Africa. S Afr J Psychiatry. 2012;18(2):42-6.

53. Isfahani P, Arefy M, Peyravi S, Bahador RC, Afshari M. A systematic review and meta-analysis of job stress among Iranian nurses. BMC Public Health. 2020:1.

54. Al-Makhaita HM, Sabra AA, Hafez AS. Predictors of work-related stress among nurses working in primary and secondary health care levels in Dammam, Eastern Saudi Arabia. J Fam Community Med. 2014;21(2):79-84. https://doi.org/10.4103/2230-8229.134762.

55. Al-Hawajreh K: Exploring the relationship between occupational stress and organizational commitment among nurses in selected jordanian hospitals. 2011

56. Office IL: Global employment trends 2013: recovering from a second jobs dip: international labour Office-ILO; 2013.

57. Kakemam E, Raeissi P, Raoofi S, Soltani A, Sokhanvar M, Visentin DC, Cleary M. Occupational stress and associated risk factors among nurses: a crosssectional study. Contemp Nurse. 2019;55(2-3):237-49. https://doi.org/10.1 080/10376178.2019.1647791.

58. Perkbox: THE 2018 UNITED KINGDOM WORKPLACE STRESS SURVEY In United Kingdom; 2018. https://pages.perkbox.com/rs/244-RYY-693/images/2 018-Workplace-Stress-Survey.pdf.

59. Gray-Toft P, Anderson JG. The nursing stress scale: development of an instrument. J Behav Assess. 1981;3(1):11-23. https://doi.org/10.1007/ BF01321348.

60. Jafari S, Batebi A, Hosseini M, Ebrahimpoor M, Shojaei F, Vaezi M. The effects of occupational stress on quality of life and associated factors among hospital nurses in Iran. J Soc Dev Sci. 2012;3(6):194-202. https://doi.org/1 $0.22610 /$ jsds.v3i6.703.

61. Yada H, Abe H, Omori H, Matsuo H, Masaki O, Ishida Y, Katoh T. Differences in job stress experienced by female and male Japanese psychiatric nurses. Int J Ment Health Nurs. 2014;23(5):468-76. https://doi.org/10.1111/inm.12080.

\section{Publisher's Note}

Springer Nature remains neutral with regard to jurisdictional claims in published maps and institutional affiliations.

Ready to submit your research? Choose BMC and benefit from:

- fast, convenient online submission

- thorough peer review by experienced researchers in your field

- rapid publication on acceptance

- support for research data, including large and complex data types

- gold Open Access which fosters wider collaboration and increased citations

- maximum visibility for your research: over $100 \mathrm{M}$ website views per year

At $\mathrm{BMC}$, research is always in progress.

Learn more biomedcentral.com/submission 